\title{
EFFECT OF NITROGEN, PHOSPHORUS AND POTASSIUM FERTILIZATION ON THE CONTENT OF MACROELEMENTS IN FRUITS OF AUBERGINE (SOLANUM MELONGENA L.) GROWN ON ORGANIC SUBSTRATES
}

\author{
Bartosz Markiewicz, Anna Golcz, Tomasz Kleiber, \\ Maciej Bosiacki
}

\author{
Chair of Horticultural Crop Fertilization \\ University of Life Sciences in Poznań
}

\begin{abstract}
A plant growing experiment was conducted in 2003-2004 on the aubergine cultivars Epic $F_{1}$ and Solara $F_{1}$ grown in an unheated polyethylene tunnel greenhouse at the Experimental Station in Marcelin, the University of Life Sciences in Poznan. The seedlings were planted on 15 May on beds at a $0.5 \times 0.5 \mathrm{~m}$ spacing, i.e. 4 plants $\mathrm{m}^{-2}$, in $6 \mathrm{dm}^{3}$ cylinders filled with substrate limed to $\mathrm{pH}_{\mathrm{H}_{2} \mathrm{O}}=6.5$, which consisted of: 1) highmoor peat from Lithuania, 2) pine bark from the pulp plant Zakłady Celulozowe + fen peat from Biskupice near Poznań ( $\mathrm{v}: \mathrm{v}=1: 1)$. The basic fertilization, i.e. pre-vegetation fertilization and top dressing with macronutrients, based on an analysis of the substrate was applied, using the universal method in $0.03 \mathrm{M} \mathrm{CH}_{3} \mathrm{COOH}$. The fertilization was designed to achieve the following substrate abundance levels: $\mathrm{L}\left(\mathrm{N}-300, \mathrm{P}-265, \mathrm{~K}-500 \mathrm{mg} \mathrm{dm}^{-3}\right), \mathrm{S}(\mathrm{N}-400$, $\left.\mathrm{P}-350, \mathrm{~K}-665 \mathrm{mg} \mathrm{dm}{ }^{-3}\right), \mathrm{H}\left(\mathrm{N}-500, \mathrm{P}-440, \mathrm{~K}-830 \mathrm{mg} \mathrm{dm}^{-3}\right)$, while maintaining the $\mathrm{N}: \mathrm{P}: \mathrm{K}$ ratio as $1: 0.9: 1.7$.

The aim of this study has been to determine the effect of nitrogen, phosphorus and potassium on the content of macronutrients in fruits of two aubergine cultivars grown on organic substrates. The fruits were harvested in the first decade of August and underwent chemical analyses in order to determine concentrations of macroelement. For determination of the total forms of nutrients, the fruit samples were subjected to wet mineralization and the following nutrients were assayed: N, P, K, Ca, Mg. Significant differences between
\end{abstract}

dr inż. Bartosz Markiewicz, Chair of Horticultural Crop Fertilization, University of Life Sciences in Poznań, Zgorzelecka 4, 60-198 Poznań, phone: (061) 8466312, e-mail: bartosz.markiewicz@wp.pl 
the cultivars were found only in the mean concentration of potassium, (Epic $\mathrm{F}_{1}-26.65 \mathrm{~g}$ $\mathrm{K} \mathrm{kg}{ }^{-1}$ d.m, Solara $F_{1}-29.72 \mathrm{~g} \mathrm{~K} \mathrm{~kg}{ }^{-1}$ d.m) while the concentrations of nitrogen and calcium were significantly different between the substrate variants. No effect of the fertilization level on the mean content of nitrogen, phosphorus, potassium, magnesium or sulfur was found in aubergine fruits.

Key words: aubergine, fruits, macronutrients.

\title{
WPLYW NAWOŻENIA AZOTEM, FOSFOREM I POTASEM NA ZAWARTOŚĆ MAKROELEMENTÓW W OWOCACH OBERŻYNY (SOLANUM MELONGENA L.) UPRAWIANEJ W PODŁOŻACH ORGANICZNYCH
}

\begin{abstract}
Abstrakt
W latach 2003-2004 przeprowadzono doświadczenia wegetacyjne z uprawą oberżyny odm. Epic $\mathrm{F}_{1}$ i Solara $\mathrm{F}_{1} \mathrm{w}$ nieogrzewanym tunelu foliowym, w Stacji Doświadczalnej Marcelin Uniwersytetu Przyrodniczego w Poznaniu. Rośliny sadzono 15 maja na zagonach w rozstawie $0,5 \times 0,5 \mathrm{~m}$, tj. 4 rośliny $\mathrm{m}^{-2}$, w cylindrach o objętości $6 \mathrm{dm}^{3}$ wypełnionych podłożem zwapnowanym do $\mathrm{pH}_{\mathrm{H}_{2} \mathrm{O}}=6,5$. Skład podłoża to: 1) torf wysoki z Litwy, 2) kora sosnowa z Zakładów Celulozowych + torf niski z Biskupic k. Poznania (v : v = 1: 1). Nawożenie podstawowe - przedwegetacyjne i pogłówne makroskładnikami oparte na analizie podłoża wykonanej metodą uniwersalną w $0,03 \mathrm{M} \mathrm{CH}_{3} \mathrm{COOH}$ - ustalono do założonych poziomów: $N\left(\mathrm{~N}-300, \mathrm{P}-265, \mathrm{~K}-500 \mathrm{mg} \mathrm{dm}^{-3}\right), S\left(\mathrm{~N}-400, \mathrm{P}-350, \mathrm{~K}-665 \mathrm{mg} \mathrm{dm}^{-3}\right)$, $W\left(\mathrm{~N}-500, \mathrm{P}-440, \mathrm{~K}-830 \mathrm{mg} \mathrm{dm}^{-3}\right)$ z zachowaniem proporcji makroskładników $\mathrm{N}: \mathrm{P}$ : $\mathrm{K}=1: 0,9: 1,7$. Celem pracy było określenie wpływu nawożenia azotem, fosforem i potasem na zawartość makroelementów w owocach 2 odmian oberżyny uprawianej w podłożach organicznych. Owoce do analiz chemicznych na zawartość makroelementów zebrano w I dekadzie sierpnia, poddano mineralizacji i oznaczono zawartość: $\mathrm{N}, \mathrm{P}, \mathrm{K}, \mathrm{Ca}, \mathrm{Mg}$. Większą zawartość azotu oznaczono w owocach roślin uprawianych w torfie wysokim $\left(13,69 \mathrm{~g} \mathrm{~N} \mathrm{~kg}^{-1}\right.$ s.m.) w porównaniu z uprawianymi w mieszaninie kory z torfem $(11,65 \mathrm{~g} \mathrm{~N}$ $\mathrm{kg}^{-1}$ s.m.). Istotne różnice $\mathrm{w}$ średniej zawartości składnika, porównując odmiany, stwierdzono tylko w zawartości potasu w owocach (Epic $\mathrm{F}_{1}-26,65 \mathrm{~g} \mathrm{~K} \mathrm{~kg}^{-1} \mathrm{~s} . \mathrm{m}$, Solara $\mathrm{F}_{1}-$ $29,72 \mathrm{~g} \mathrm{~K} \mathrm{~kg}^{-1} \mathrm{~s} . \mathrm{m}$ ), natomiast analizując rodzaj podłoża - w przypadku azotu i wapnia. Nie stwierdzono wpływu poziomu nawożenia na średnią zawartość azotu, fosforu, potasu, magnezu i siarki w owocach oberżyny.
\end{abstract}

Słowa kluczowe: oberżyna, owoce, makroelementy.

\section{INTRODUCTION}

Aubergine fruits are valued for their taste and dietary properties. Fleshy, low-calorie (15-24 kcal) aubergines are not a significant source of vitamins (small amounts of vitamins B, PP, L-ascorbic acid) but they are rich in minerals. Aubergines possess a highly advantageous composition of minerals, i.e. much potassium, calcium, iron and phosphorus but little sodium (CEBULA 1996). $100 \mathrm{~g}$ of fresh aubergine fruit contains $220 \mathrm{mg}$ potassium, which covers $10 \%$ of daily allowance for that nutrient (HeRManN 1996). Moreover, aubergine fruits contain chlorine ( $52 \mathrm{mg} \%$ ), phosphorus (up to $47 \mathrm{mg} \%$ ), sulfur 
(44 mg\%), similar amounts of calcium and magnesium (from 11 to $18 \mathrm{mg} \%$ ), as well as iron, manganese, copper and zinc (HERMANN 1996).

The aim of this study has been to determine the effect of nitrogen, phosphorus and potassium on the content of macroelements in fruits of 2 cultivars of aubergine grown on organic substrates.

\section{MATERIAL AND METHODS}

A plant-growing experiment was conducted in 2003-2004 on the aubergine cultivars Epic $F_{1}$ and Solara $F_{1}$ grown in an unheated polyethylene tunnel greenhouse at the Experimental Station in Marcelin, the Poznan University of Life Sciences. The seedlings were planted on 15 May on beds at a 0.5 × $0.5 \mathrm{~m}$ spacing, i.e. 4 plants $\mathrm{m}^{-2}$, in $6 \mathrm{dm}^{3}$ cylinders filled with substrate limed to $\mathrm{pH}_{\mathrm{H} 2 \mathrm{O}}=6.5$, which consisted of: 1) highmoor peat from Lithuania, 2) pine bark from the pulp plant Zakłady Celulozowe + fen peat from Biskupice near Poznań ( $\mathrm{v}: \mathrm{v}=1: 1$ ). Basic fertilization, i.e. prevegetation fertilization and top dressing with macronutrients, based on analysis of the substrate, was applied using the universal method in $0.03 \mathrm{M}$ $\mathrm{CH}_{3} \mathrm{COOH}$. The fertilization pattern was designed to achieve substrate abundance levels: low $(\mathrm{N})$, standard $(\mathrm{S})$ and high $(\mathrm{W})$, while maintaining the $\mathrm{N}: \mathrm{P}: \mathrm{K}$ ratio at $1: 0.9: 1.7$ (Table 1 ). The other macro- and micronutrients constituted the background of the experiment.

Table 1

Nutrient levels in the pre-vegetation and top dressing fertilization of aubergine

\begin{tabular}{|c|c|ccc|}
\hline \multirow{2}{*}{ Nutrient } & \multicolumn{4}{|c|}{ Fertilization } \\
\cline { 2 - 5 } & \multicolumn{4}{|c|}{ top dressing } \\
\cline { 2 - 5 } & pre-vegetation dm \\
\cline { 2 - 5 } & L S H & L & S & H \\
\cline { 2 - 5 } N & 350 & 300 & 400 & 500 \\
P & 310 & 265 & 350 & 440 \\
K & 580 & 500 & 665 & 830 \\
$\mathrm{Ca}$ & \multicolumn{4}{|c}{$1500-2000$} \\
\hline
\end{tabular}

The top dressing treatment was performed 3 times at 4 -week intervals. Deficiencies of nitrogen, phosphorus and potassium were supplemented to the established levels. Mineral fertilizers $\mathrm{NH}_{4} \mathrm{NO}_{3}, \mathrm{KH}_{2} \mathrm{PO}_{4}$ and $\mathrm{K}_{2} \mathrm{SO}_{4}$ were applied in the experiment. 
All agricultural measures were performed following the current recommendations for auberginecultivation. Fruits were picked several times at the picking maturity stage. Fruits for chemical determination of concentrations of macronutrients were harvested in the first decade of August. In order to determine the total forms of nutrients, fruit samples were subjected to wet mineralization in:

- sulfosalicylic acid, using sodium thiosulfate as a reducer and a selenium mixture as a catalyst - in order to determine nitrogen,

- sulfuric acid in the presence of an oxidant $\mathrm{H}_{2} \mathrm{O}_{2}$ - in order to determine the other macronutrients (except nitrogen).

After mineralization of the plant material, the following determinations were performed:

- total $\mathrm{N}$ - by distillation according to Kjeldahl in a Parnas-Wagner apparatus,

- P - by colorimetry with ammonia molibdate (according to Schillak),

- K, Ca - by flame photometry,

- Mg - by atomic absorption spectrometry (AAS).

- $\mathrm{S}$ - by nephelometry with $\mathrm{BaCl}_{2}$.

The results of the chemical analyses were analyzed statistically using Duncan's test at the significance á $=0.05$.

\section{RESULTS AND DISCUSSION}

Fruits of both aubergine cultivars contained varied contents of macroelements depending on the substrate and fertilization levels. Higher concentrations of nitrogen were found in fruits of plants grown on highmoor peat (13.69 $\mathrm{g} \mathrm{N} \mathrm{kg}^{-1}$ d.m.) in comparison to those grown on a mixture of bark and peat (11.65 $\mathrm{g} \mathrm{N} \mathrm{kg}^{-1} \mathrm{~d}$.m.). Fruits from the highmoor peat variant contained more nitrogen at the low and high fertilization levels in comparison to the standard level. However, no significant differences were found in the mean nitrogen content in fruits of both cultivars at different fertilization levels. The results concerning the nitrogen content in fruits of both aubergine cultivars were markedly lower than those reported by MichAŁOJć and Buczkowska (2008, 2009), who studied the effect of nitrogen fertilizer, the method of plant habit formation as well as the rate and type of potassium fertilizer and obtained results close to $\pm 20 \mathrm{~g} \mathrm{~N} \mathrm{~kg}^{-1} \mathrm{~d} . \mathrm{m}$.

In aubergine fruits, more phosphorus was determined than found by Michąojć, Buczkowska (2008, 2009). The posphorus content in fruits of both cultivars grown in the mixed substrate increased with an increasing level of fertilization, but the differences were not significant. Similarly, no significant differences between cultivars or fertilization levels were recorded in the phosphorus content in fruits. 
Table 2

Mean content of macronutrients in aubergine fruits depending on the cultivar, substrate and fertilization level in 2003-2004.

\begin{tabular}{|c|c|c|c|c|c|c|c|c|}
\hline \multirow{2}{*}{ Cultivar } & \multirow{2}{*}{ Substrate } & \multirow{2}{*}{$\begin{array}{l}\text { Fertiliza- } \\
\text { tion level }\end{array}$} & \multicolumn{6}{|c|}{ Nutrient solution (g kg-1 d.m.) } \\
\hline & & & $\mathrm{N}$ & $\mathrm{P}$ & K & $\mathrm{Ca}$ & $\mathrm{Mg}$ & $\mathrm{S}$ \\
\hline \multirow{6}{*}{ Epic $\mathrm{F}_{1}$} & \multirow{3}{*}{ highmoor peat } & $\mathrm{L}$ & 14.40 & 5.02 & 28.47 & 0.90 & 1.80 & 1.87 \\
\hline & & $\mathrm{S}$ & 12.17 & 4.82 & 25.62 & 0.70 & 1.62 & 1.80 \\
\hline & & $\mathrm{H}$ & 14.32 & 4.45 & 25.57 & 0.80 & 1.40 & 1.70 \\
\hline & \multirow{3}{*}{$\begin{array}{c}\text { pine bark }+ \text { low - } \\
\text { moor peat }\end{array}$} & $\mathrm{L}$ & 10.20 & 3.92 & 26.10 & 1.10 & 1.50 & 1.75 \\
\hline & & $\mathrm{S}$ & 10.05 & 4.30 & 27.02 & 0.90 & 1.55 & 1.60 \\
\hline & & $\mathrm{H}$ & 11.10 & 4.32 & 27.10 & 0.97 & 1.57 & 1.80 \\
\hline \multirow{6}{*}{ Solara $\mathrm{F}_{1}$} & \multirow{3}{*}{ highmoor peat } & $\mathrm{L}$ & 13.50 & 4.47 & 28.12 & 0.92 & 1.47 & 1.65 \\
\hline & & $\mathrm{S}$ & 12.57 & 4.60 & 28.65 & 0.82 & 1.45 & 1.77 \\
\hline & & $\mathrm{H}$ & 15.17 & 5.00 & 29.37 & 1.12 & 1.50 & 1.82 \\
\hline & \multirow{3}{*}{$\begin{array}{c}\text { pine bark + low - } \\
\text { moor peat }\end{array}$} & $\mathrm{L}$ & 12.25 & 4.22 & 30.70 & 1.22 & 1.62 & 1.75 \\
\hline & & $\mathrm{S}$ & 12.80 & 4.50 & 29.42 & 1.02 & 1.47 & 1.92 \\
\hline & & $\mathrm{H}$ & 13.52 & 5.07 & 32.07 & 1.00 & 1.47 & 1.90 \\
\hline \multicolumn{3}{|c|}{ Mean for cultivar } & $\begin{array}{l}12.04 a \\
13.30 a\end{array}$ & $\begin{array}{l}4.47 a \\
4.64 a\end{array}$ & $\begin{array}{l}26.65 a \\
29.72 b\end{array}$ & $\begin{array}{l}0.89 a \\
1.02 a\end{array}$ & $\begin{array}{l}1.57 a \\
1.50 a\end{array}$ & $\begin{array}{l}1.75 a \\
1.80 a\end{array}$ \\
\hline \multicolumn{3}{|c|}{ Mean for substrate } & $\begin{array}{l}13.69 b \\
11.65 a\end{array}$ & $\begin{array}{l}4.72 a \\
4.39 a\end{array}$ & $\begin{array}{l}27.63 a \\
28.73 a\end{array}$ & $\begin{array}{l}0.87 a \\
1.03 b\end{array}$ & $\begin{array}{l}1.54 a \\
1.53 a\end{array}$ & $\begin{array}{l}1.77 a \\
1.78 a\end{array}$ \\
\hline \multicolumn{3}{|c|}{ Mean for fertilization level } & $\begin{array}{l}12.58 a \\
11.90 a \\
13.53 a\end{array}$ & $\begin{array}{l}4.41 a \\
4.55 a \\
4.71 a\end{array}$ & $\begin{array}{l}28.35 a \\
27.68 a \\
28.53 a\end{array}$ & $\begin{array}{c}1.03 b \\
0.86 a \\
0.97 a b\end{array}$ & $\begin{array}{l}1.60 a \\
1.52 a \\
1.48 a\end{array}$ & $\begin{array}{l}1.75 a \\
1.77 a \\
1.80 a\end{array}$ \\
\hline
\end{tabular}

Means marked by the same letters do not differ significantly at the level of $\alpha=0.05$

L, S, H - fertilization level: L - low, S - standard, H - high

The highest potassium content was found in fruits of $\mathrm{cv}$. Epic $\mathrm{F}_{1}$ grown on peat at the low fertilization level $\left(28.47 \mathrm{~g} \mathrm{~K} \mathrm{~kg}^{-1} \mathrm{~d}\right.$.m. $)$ and in fruits of cv. Solara $F_{1}$ grown on the mixed substrate of lowmoor peat and bark at the high fertilization level $\left(32.07 \mathrm{~g} \mathrm{~K} \mathrm{~kg}^{-1} \mathrm{~d}\right.$.m.). Moreover, significant differences were shown in the potassium content between cultivars $\left(26.65 \mathrm{~g} \mathrm{~K} \mathrm{~kg}^{-1}\right.$ d.m. Epic $\mathrm{F}_{1}, 29.72 \mathrm{~g} \mathrm{~kg}^{-1}$ d.m. Solara $\mathrm{F}_{1}$ ). These results were similar to the ones reported by Micha£oJć and BuczKowsKa (2008, 2009).

Aubergine fruits contained from $0.70 \mathrm{~g} \mathrm{Ca} \mathrm{kg}^{-1}$ d.m. to $1.22 \mathrm{~g} \mathrm{Ca} \mathrm{kg}^{-1}$ d.m. The mean calcium concentrations did not differ significantly. However, a significant effect of the substrate on the mean calcium content was observed in aubergine fruits. At the low fertilization level aubergine fruits accumulated the highest amounts of calcium. 
In this study, no effect of cultivar, substrate or fertilization level was found on the mean content of magnesium and sulfur in aubergine fruits. Different concentrations of macronutrients in fruits, despite statistically significant differences, are confirmed by ZoRNOZA et al. (1995), who showed that genetic variation of cultivars has some effect on the differentiated uptake, translocation and accumulation of anions and cations in plants. According to KANAHAMA (1994), the nutrients which are translocated the fastest from vegetative organs to fruits include phosphorus and nitrogen; slower transport was found for potassium, while magnesium and calcium were the slowest nutrients.

\section{CONCLUSIONS}

1. Significant differences between the cultivars were found only in the mean concentration of potassium, while the concentrations of nitrogen and calcium were significantly different between the substrate variants.

2. Higher mean amounts of nitrogen were determined in fruits of plants grown on highmoor peat in comparison to the mixed substrate.

3. No effect of the fertilization level on the mean concentrations of nitrogen, phosphorus, potassium, magnesium or sulfur was found in aubergine fruits.

\section{REFERENCES}

Buczkowska H., MichaŁojć Z. 2008. Content of macroelements in eggplant fruits depending on nitrogen fertilization and plant training method. J. Elementol., 13 (2): 269-274.

Cebula S. 1996. Wptyw cięcia roślin na wzrost, plonowanie $i$ jakość owoców dwóch odmian oberżyny (Solanum melongena L.) $w$ uprawie szklarniowej [Effect of plant trimming on the growth, yield and fruit quality of aubergine (Solanum melongena L.) grown in a greenhouse]. Acta Agrar., 34: 3-11. (in Polish)

Herrmann K. 1996. Inhaltsstoffe der Auberginen. Ndustr. Obst.-u. Gemüseverwert. 9: $285-288$.

Kanahama K. 1994. Studies on fruit vegetables in Japan. Hort. Abstr., 64 (1): 1-5.

Micha£ojć Z., Buczkowska H. 2009. Content of macroelements in eggplant fruits depending on varied potassium fertilization. J. Elementol., 14 (1): 111-118.

Zornoza P., Molla E., Estaban R.M., Lopez-Andreu F.J. 1995. Response of some cultivars of eggplant to the nutrient solution concentration. Acta Hort., 412: 447-454. 